College of William \& Mary Law School William \& Mary Law School Scholarship Repository

1995

\title{
Professional Preparedness: A Comparative Study of Law Graduates' Perceived Readiness for Professional Ethics Issues
}

James E. Moliterno

\section{Repository Citation}

Moliterno, James E., "Professional Preparedness: A Comparative Study of Law Graduates' Perceived Readiness for Professional Ethics Issues" (1995). Faculty Publications. 1109.

https://scholarship.law.wm.edu/facpubs/1109

Copyright c 1995 by the authors. This article is brought to you by the William \& Mary Law School Scholarship Repository. 


\title{
PROFESSIONAL PREPAREDNESS: A COMPARATIVE STUDY OF LAW GRADUATES' PERCEIVED READINESS FOR PROFESSIONAL ETHICS ISSUES
}

\author{
JAMES E. MOLITERNO*
}

\section{INTRODUCTION}

What would happen if a law school taught professional ethics through an experiential learning-based model rather than through a free-standing professional ethics course? If asked anonymously, what would such a school's graduates say about the experiential approach after a few years of practice? How might their comments compare to what other schools' graduates might say about their more traditional free-standing, classroom-based course? That is one of a number of things we hoped to learn in conducting a survey of 1,000 lawyers who had graduated from law school within the past five years.

Part II of this article begins by describing the form of the survey sent to recent law school graduates and explaining how the law schools and graduates were chosen. Part III then discusses the curriculum of the four schools and highlights the unique aspects of William and Mary's legal skills program. Part IV examines the ways in which the data collected from the survey shows the effectiveness of William and Mary's program based on the law graduates' satisfaction with their professional ethics training.

\section{II}

\section{SURVEY DESCRIPTION AND GOALS}

The goals of the survey ${ }^{1}$ were to determine whether a relationship exists

\footnotetext{
Copyright @ 1996 Law and Contemporary Problems

* Professor of Law and Director of the Legal Skills Program, The College of William and Mary.

The data reported on in this article was developed under a grant from the Institute for Law School Teaching, Spokane, Washington. Points of view expressed are those of the author and do not necessarily reflect the position or policies of the Institute. The author thanks the W. M. Keck Foundation for its support of the Symposium on Teaching Ethics and the Legal Profession for which this paper is written and for its support of the W. M. Keck Foundation Forum on the Teaching of Legal Ethics held at William and Mary on March 22-23, 1996. The author thanks Tom Metzloff and David Wilkins for their editorial work on this issue and David Wilkins for his very helpful comments on a draft of this article. The author also thanks the following for invaluable assistance with various parts of this project: Kammy Wilson, Pamela Kultgen, Catherine Trinkle, Jonni Lyman, and Katie Phillips.

1. The survey document itself was drafted with the help of Thomas Hafemeister of the National Center for State Courts, Professor Gary Kreps of the William and Mary Sociology department, Connie Beck of the University of Arizona, Kammy Wilson, and Pamela Kultgen. The survey instrument is
} 
between the professional skills and professional ethics teaching curriculum at a law school and the school's graduates' satisfaction with their profession or their perceptions of preparedness for various types of legal practice. To gauge attorneys' satisfaction with their profession, the survey asked questions about work environment, stress levels, mental and physical health, and career goals. The survey then asked attorneys to evaluate various aspects of their law school training as preparation for their careers. This paper presents the portion of the survey's data that relates specifically to professional ethics teaching. ${ }^{2}$ Implicitly, we were evaluating the professional ethics curriculum experiment that William and Mary has conducted since 1988 .

Four law schools were chosen to participate in the survey. Although no two law schools are identical, these schools were chosen because they have much in common. $^{3}$ Each is a state-supported law school with a long tradition of excellence. Their U.S. News and World Report rankings for 1993, 1994, and 1995 range from the high teens to the mid to high thirties and in any given year are within a range of eighteen. ${ }^{4}$ During those three years, William and Mary's rank has been thirty-two (1993), ${ }^{5}$ twenty-nine (1994), ${ }^{6}$ and twenty-eight (1995). ${ }^{7}$ In any given year, the three other schools have been no more than ten ranks higher or lower than William and Mary. Although somewhat different in size, none would be called either very small or very large: the smallest has 550 students, two others have 700 students, and the largest has 900 students. Only one of the four schools has a part-time division, and that enrolls less than 10 percent of the school's students. The credentials of their students are comparable and high, all with median LSATs in the upper 15 percent. $^{8}$

available from the author upon request.

2. Later papers will present a more general report on the survey's data.

3. I thank each of the participating schools for agreeing to take part in this survey project. Without the schools' willingness to do so, the project would have been impossible to complete. Administrators at each of the schools consented to participate in the survey and indeed supplied us with the mailing lists to facilitate it. The reader will notice that the three participating schools other than William and Mary are identified by description rather than name. What is important for the survey's purposes are the many similarities among the four schools and the differences in skills and ethics teaching curricula, all of which are described in this article; little more is to be gained by adding the schools' names.

4. We all have our respective misgivings about the quality and accuracy of the ranking system. Nonetheless, it serves as a third party's assessment on several discrete issues including resources, and student and faculty quality and ratios. While far from perfect, the similarity in rankings says something about the qualitative similarity of the institutions.

5. America's Best Graduate Schools: The Top 25 Law Schools, U.S. NEws \& WORLD REP., Mar. 20,1995 , at 77,85 .

6. Id. Mar. 21,1994 , at 65,73 .

7. Id., Mar. 22, 1993, at 51, 64.

8. 1994-95 ABA report data for the four schools reveals the following about student credentials:

School 1

Median LSAT Median undergraduate GPA

$\begin{array}{lll}\text { School } 2 & 160 & 3.50 \\ & 161 & 3.45\end{array}$

$\begin{array}{lll}\text { School } 3 & 161 & 3.45\end{array}$

W\&M $\quad 164 \quad 3.43$

This report is not publicly available but is provided by the ABA to most law school administrations. 
One of the four schools is my own: William and Mary Law School. To guard against either a positive or negative impact on William and Mary students' answers to the survey questions that might attend their knowledge of my connection with the study, the surveys were mailed under the cover stationery and with stamped, return-addressed envelopes of the Institute for Law School Teaching from Spokane, Washington. As such, there was no reason for graduates of any of the schools to expect that they were being surveyed by someone from their own school. ${ }^{9}$

One thousand surveys were sent to graduates of these four law schools, 250 from each school, spread as evenly as possible over four years of graduates from 1990 to 1993, and randomly selected from mailing lists provided by each school. ${ }^{10}$ Thus, when answering the surveys in March and May of 1995, the lawyers surveyed had been out of law school for approximately two to five years.

These junior attorneys arguably provide the most insightful information about their law school training and its relation to their preparation for and satisfaction with the practice of law. One might also ask their supervisors, though doing so would eliminate evaluation by solo practitioners, small office lawyers, and attorneys working in large offices who are receiving less supervision than would be needed to credit the views of supervisory lawyers. One might also ask their clients, but many impairments regarding the clients' ability to evaluate, the lawyers' unwillingness to give clients' names, or skew the names given, and a surveyor's ability to evaluate clients' comments would limit the value of such information. One might also ask their former professors, whose knowledge would be quite limited on this matter. One might ask lawyers who had been in the practice longer and who could therefore take a more seasoned view of their abilities, but they would have a more difficult time attaching significance to the effect of their law school experience on their preparation than might more recent graduates. Nonetheless, these other available sources of information could be used to develop data for comparison with that generated by the current survey.

Of the 1,000 surveys initially sent to recipients in March 1995, thirty-two were returned "undeliverable," leaving 968 that presumably reached their respective recipients. Of those 968,323 were completed and returned, for a 33 percent return rate.

Although a 33 percent return rate would probably be adequate to draw conclusions, my hope had been to achieve a somewhat higher return. On May 22,1995 , a second mailing was sent to the 645 recipients of the first mailing that

9. Copies of each school's returned surveys were mailed to the respective schools; copies of all the returned surveys are on file with the Institute for Law School Teaching in Spokane, Washington.

10. To select the survey recipients, we started with the mailing lists provided by the alumni administrators at the four schools. We determined the total number of alumni on each list and divided that number in each case by 250 . That process yielded a number (n) for each school. Choosing the nth name on each respective list yielded 250 names from each of the four schools. 
had not returned the survey. That cover letter asked for the survey's return in the postage prepaid envelope by June 12,1995. Eighty completed surveys were generated by this second mailing, and thirteen more were returned as undeliverable.

In summary, of the 1,000 surveys mailed, 955 presumably reached the addressee. A total of 404 completed surveys have been returned for a 42.3 percent response rate. Fortunately, the 404 surveys returned are reasonably well balanced across the four schools: School 1-98; School 2-110; School 3-90; William and Mary-99; ${ }^{11}$ and Miscellaneous-7. ${ }^{12}$

\section{III}

\section{Professional Ethics AND Related CURRICULA AT THE EXAMINED SCHOOLS ${ }^{13}$}

All four of the schools in the survey have fairly traditional curricula, with the exception of the professional skills and professional ethics teaching program at William and Mary.

\section{A. General Curricula at the Four Schools}

With relatively minor variations, the general curricula at the four schools are quite similar. Placing programs and courses dealing explicitly with professional skills and professional ethics to the side, the current, standard law school curriculum is roughly as follows: required first-year courses in contracts, constitutional law, torts, property, civil procedure, and criminal law, and secondand third-year offerings of elective courses in advanced topics related to all firstyear courses, seminars in narrower slices of these areas, courses or seminars in "law and another discipline," and perspective or enrichment courses or seminars.

\section{B. Legal Research and Writing, Professional Ethics, and Clinical Teaching} Curricula at Schools 1, 2, and 3

The traditional law school professional skills and professional ethics curriculum includes the following features: (1) a required first-year legal research and writing course; (2) a required upperlevel professional ethics course and various upperlevel elective ethics-issue seminars; and (3) a variety of clinical

11. Twenty of the 99 William and Mary surveys are from 1990 graduates. Because the legal skills program began with the entering class of 1988, these 1990 graduates did not participate in the program. The remaining 79 surveys are from 1991-93 graduates who participated in the program during its first three years of operation.

12. Because some of the four targeted schools have LL.M. programs, a few LL.M. degree holders were among the survey's recipients. Because these lawyers had not received J.D.'s from the targeted schools, and therefore had not experienced the curricula that the survey was intended to evaluate, the data from their completed surveys are not included in the result data.

13. The descriptions of curricula that follow are drawn from the four schools' catalogues and occasionally from an academic regulation that is not apparent from a reading of the catalogue. 
and professional skills courses, including elective, limited enrollment simulated skills courses (such as Trial Advocacy, Negotiation, Interviewing and Counseling, and Document Drafting), elective, limited enrollment live client clinical courses, and externship placements outside the law school. Schools 1, 2, and 3 in the survey roughly follow this pattern.

1. Legal Research and Writing Curricula. At School 1, first-year students must complete a year-long, four-credit course in research, reasoning, writing, and advocacy. During their second year, School 1 students must enroll in a small-section class. Providing instruction in any of a variety of legal fields, these small-section courses incorporate specially designed written assignments into a substantive law context.

School 2's first-year students must complete a year-long legal research and writing program. In a small-group environment, this three-credit class covers basic techniques for writing legal memoranda and court briefs and assists students in developing oral advocacy skills. School 2 also offers Advanced Legal Writing and Appellate Advocacy II.

At School 3, first-year students take a course in legal bibliography and a separate writing course that runs in conjunction with their small-section substantive law course. Prior to graduation, School 3's upperlevel students must take an appellate advocacy class during their second year and earn five additional writing credits.

2. Professional Ethics Curricula. Second-year students at School 1 must complete a course in professional ethics. However, in an effort to accommodate its students' individualized interests, School 1 offers a variety of professional ethics courses emphasizing different aspects of the subject material. School 1's catalogue lists the following professional ethics elective courses: Ethics in Criminal Practice; Professional Responsibility of the Litigator; Ethics in the Adversary Process; Professionalism and Morality; Ethical Issues in Trusts and Estates; Ethics in Tax Practice; and Bioethics and Law.

School 2 requires a one- to three-credit professional ethics course that focuses primarily on the codes of attorney conduct. School 2's catalogue lists the following professional ethics electives: Selected Problems in Professional Responsibility Seminar and Legal Profession.

School 3 students must complete an upperlevel course in professional ethics. School 3's catalogue lists the following elective professional ethics courses: Hard Cases: Science Policy and Values; Ethical and Economic Realities of Legal Practice; and Lying by Lawyers and Their Clients Seminar.

3. Clinical and Professional Skills Curricula. School 1's third-year students may engage in independent research projects and develop practical lawyering skills through a trial advocacy course, criminal and civil clinical programs, and skills classes such as Interviewing and Counseling. School 1's elective offerings include the following: Advanced Legal Research; Civil Legal Assistance Clinic; 
Criminal Law Clinic; Interviewing, Counseling, and Negotiation; Lawyering Process-Civil; Lawyering Process-Criminal; Trial Advocacy; Administrative Process and Advocacy; Supreme Court Practice and Appellate Advocacy; and Appellate Defender Seminar.

School 2 offers numerous clinical and professional skills electives, including Legal Assistance to Institutionalized Persons Program, Labor Law Clinical Program, Administrative Advocacy Program, Environmental Law Clinic, Clinical Seminar-Prosecution, Trial Advocacy, and General Practice Course. School 2 also offers a variety of externship opportunities to its upperclass students.

School 3's students may elect to take a maximum of fifteen credits through clinical programs that run in conjunction with various legal services organizations, the federal Bankruptcy Court, and the state and federal attorneys general offices. A student can accumulate up to six credits through externships with local nonprofit organizations and governmental agencies.

School 3's students may also enroll in several electives: Law, Litigation, and Science; Negotiations; Alternative Dispute Resolution Methods; Trial Advocacy; Advanced Trial Advocacy; Trial Advocacy Enhanced; Clinical Law ProgramInternship; Clinical Law Program-Externship; Clinical Semester; Client Counseling I; and Corporation Law Practicum.

\section{Legal Research and Writing, Professional Ethics, and Clinical Teaching} at William and Mary

Although William and Mary's general curriculum is traditional, its professional skills and professional ethics curriculum is not. Training in these two areas occurs primarily in a required, two-year legal skills program. This program revolves around long-term, comprehensive, simulated client service. Each of the other three schools in the survey has a more extensive live client clinical program and more extensive elective skills and professional ethics offerings. Beyond the required legal skills program, William and Mary's catalogue at the time of the survey listed no professional ethics electives and the following short list of skills and clinic electives: Advanced Research Techniques; Attorney General Practice Clinic; Clinical Practice; Employee Relations Clinic; Legal Aid Clinic; Legal Clerking; Trial Advocacy; and Virginia Court of Appeals Clinic.

The three principal goals of William and Mary's legal skills program are to (1) impart information about theories of and help develop essential professional skills, (2) sensitize students to the ethical issues they will face as lawyers and teach the law governing lawyers, and (3) augment and reinforce more traditional academic approaches.

Among the premises underlying the program's design is the idea that professional ethics teaching is fundamentally different from that of other law fields. Lawyers typically interact with tort law, contract law, constitutional law, and so on as an expert only. The lawyers' contact with the law is through the experiences of clients who have direct interaction with the implications of the 
legal principles. In other words, the lawyer experiences most law vicariously. Lawyers sometimes experience the law of lawyering, or the law of professional ethics, in the same way-through another's direct interaction, as, for example, when objective analysis of another lawyer's conduct is at issue. As a result, some of the teaching of the law of lawyering should look and feel like the teaching of all the other subjects covered in the curriculum. But the law and ethics of the legal profession are different from other areas in a fundamental way. The base-level interactions with the law of lawyering are direct for lawyers. Lawyer interaction with clients, courts, the society, and one another are the base-level interactions on which the law operates. Therefore, unlike other law subjects, certain benefits can be gained in teaching professional ethics through directed, designed experiences. ${ }^{14}$

To gain these benefits, professional skills instruction in William and Mary's legal skills program proceeds on two concurrent "tracks": classroom instruction and simulated client representation. Because client representation is the methodological core of the program, the entire program is organized around a simulated law office and its need to deliver effective, competent, and ethical service to clients.

The staff and students in the program are organized into firms, offices, working groups, and teams. Each entering class is divided into twelve offices, each of which is typically composed of approximately sixteen students serving as associates, one faculty member serving as senior partner, and one third-year student teaching assistant serving as junior partner. A firm is composed of all of the offices headed by a single faculty member. In most cases (because most faculty involved lead only one office from a given entering class), an office of first-year associates, an office of second-year associates, a faculty member senior partner, and a teaching assistant junior partner form a single firm. The associates in each office are divided into four working groups of approximately four associates each; each working group is divided into two teams of two associates.

The client roles are played by third-year students, students in the program, and members of the community. All of the long-term roles are played by other students in the program. Enough variation in the problem materials exists so that no student plays a role in a case in which his or her law office has any representation responsibility. The client role-playing has itself proved to be a valuable learning experience for the students. Associates serve four clients over the two-year course. The four client phases of the program are referred to in administrative terms as Clients $\mathrm{A}, \mathrm{B}, \mathrm{C}$, and $\mathrm{E}^{15}$

14. See James E. Moliterno, An Analysis of Ethics Teaching in Law Schools: Replacing Lost Benefits of the Apprentice System in the Academic Atmosphere, 60 U. CIN. L. REV. 83 (1991).

15. When it began, the program also included a Client $D$. Client $D$ was a set of domestic relations scenarios, each of which supported a mediation activity by students. The Client $\mathrm{D}$ experience was judged to be ineffective, largely because of failings in the capacity of role players to portray disputing domestic partners realistically. Client $\mathrm{D}$ was removed from the program, without relettering Client $\mathrm{E}$, 
Client A presents a non-litigation oriented, one-semester-long client matter. Each of the twelve different Client A scenarios is a dispute between businesspeople that the client-characters dictate will be settled through negotiation. Much of the program's instruction in interviewing, negotiating, and document drafting, along with the attendant lawyer-client relationship, confidentiality, conflict of interest, and truth-telling issues, occurs in the context of Client A's representation activity.

Client B presents a litigation-oriented, three-and-one-half-semester-long civil case that involves both factual and legal disputes between individuals. The twenty-four Client B cases involve fraud by silence in real estate transactions, dismissal from "at will" employment, lawyer malpractice, intentional tort conspiracy/duress issues, unconscionability in a consumer contract, and malicious prosecution of a civil matter. Much of the teaching of legal research and writing, fact investigation, court document drafting, discovery, motion, trial, and appellate practice, along with the attendant advocacy and third-party fairness issues, occurs in the context of Client B's representation activity.

The Client B activity is the longest of the four representation activities. The students begin work for Client B in October of their first year and do not conclude Client B's matter until the end of the spring semester of their second year. Each activity of the scenario is preceded by classroom material focused on the theory of the activity and is followed by critique of the activity. During the nearly three-and-one-half semesters, students, at a minimum, ${ }^{16}$ follow the schedule outlined below.

During the fall semester of their first year, students begin the scenario by interviewing their client and opening a file for the matter. Then, during the spring semester, students interview witnesses, meet with opposing counsel, update their client, do the necessary research on claims and defenses, report on the results of their research, and write an intra-office memorandum of law analyzing the claims and defenses. Toward the end of the semester, the plaintiff's lawyers draft and file a complaint, the defendant's lawyers draft and file an answer, the plaintiff's attorneys draft and file a reply (if necessary), both parties exchange information in mandatory discovery pursuant to Federal Rule of Civil Procedure 26, and students research and write another intra-office memorandum of law on a discovery issue.

The scenario continues during the second year of law school when the students participate in a discovery conference, research and write a motion and accompanying memorandum of law regarding the discovery issue upon which the late spring intra-office memorandum was based, present motion arguments, draft and serve a set of interrogatories, attend a client meeting to respond to interrogatories posed by opposing counsel, and prepare for trial. During the

in the hope that at some point Client D could be reincorporated.

16. I say at a minimum because the listed activities are all assigned and completed by the students. Students are free, however, to pursue other motions and some limited discovery activities that are not specifically assigned. 
second-year spring semester, students try their case in court, review the record (video and transcript) for error, file a notice of appeal (if they lost at trial), draft and file an appellate brief, and, finally, present their appellate arguments.

Client $\mathrm{C}$ presents a one-and-one-half-semester criminal case. Twenty-four unrelated criminal case scenarios are simultaneously run for this client phase. The Client $\mathrm{C}$ phase includes skills of interviewing, negotiating, trial and appellate practice, along with attendant confidentiality and advocacy issues, all in the special context of criminal case representation.

Client $\mathrm{E}$ is a final, shorter-term client served by the students in the fourth semester of the program. To some extent, this last client is the capstone of the course of study. This client presents the student associate with a significant ethical challenge at the same time that the classroom portion of the course is reviewing professional ethics issues and students are preparing for the law of lawyering examination that is administered at the close of the program's fourth semester. The forty-plus Client E scenarios require students to analyze carefully a statutory scheme and administrative law material.

Client $\mathrm{E}$ presents a challenging problem to students that requires them to integrate many of the elements previously covered by the legal skills program. For example, associates may be presented with a client who has been refused assistance by the state department of welfare, thus requiring the associates to analyze the federal AFDC regulations. Other associates may be presented with securities problems, tax disputes, civil RICO problems, and so on. Each of the Client E scenarios produces some emergency experience, such as seeking a temporary restraining order from a federal district court, assisting a client in making a crucial decision by an immovable deadline, or negotiating an agreement with other represented parties on a tight schedule.

A number of features distinguish the program from other skills development programs organized around a law office structure, particularly regarding professional skills and professional ethics teaching. Importantly, the legal skills program is the required professional ethics course at William and Mary; as such, ethics is not a side topic that is treated only to the extent that time will allow. Rather, the program's day-to-day teaching is built around the demands of ethics teaching. Professional ethics considerations permeate every phase of the program's two-year operation and are approached from a wide variety of perspectives.

On one level, the program provides students with experiential learning regarding issues of professional ethics. The treatment of ethics within the context of the simulations allows the experiences to become more than mere games. While there remains no doubt that the depth of emotional impact of live client experience exceeds that of simulated client representation, the inclusion of ethics teaching ensures that the simulations are realistic and textured representations of client service. For example, teaching the professional ethics issues regarding truth-telling in negotiation while also teaching negotiation tactics allows the program coordinators to imbue the negotiating 
experience with legitimate client and lawyer considerations other than merely beating an opponent.

This aspect of the program speaks to the sound criticism of the gaming that is involved in many practice skills programs. It matters that the students' clients are not "paper clients," but are individuals with whom the student lawyers interact over the term of the simulation. The combination of professional ethics topics with the teaching of professional skills has led students to consider the moral and ethical dilemmas they will face in their activities to at least as great an extent as they consider the tactics and strategies that will play a role in the activities. In fact, the goal is for students to come to see the ways in which legal ethics and techniques connect with individual lawyer activities.

The classroom experiences of the students nearly always have a professional ethics component. The weekly office meetings frequently have an explicit ethics aspect to them, as, for example, meetings to discuss soon-to-be or recently completed negotiations, interviews, motion hearings, and trials. Many of the discussions in the classroom setting are strikingly similar to discussions of issues in a free-standing professional ethics course. Cases, rules, hypothetical problems, and readings that raise questions about the value and wisdom of those rules form the base of those discussions. Other class sessions, however, are quite different from and richer than the usual professional ethics course discussion: Rather than focusing on appellate decisions, rules, or readings, they focus on the recent experiences of the students in their simulated cases and the issues that have arisen (usually by our own design).

During the two-year course, students are required to produce a number of short writings addressing professional ethics questions. They address frivolous claim concerns when they are preparing to draft their first pleadings; they address a potential conflict of interest that representation of their initial client may pose; they write about an entry to the bar and reporting misconduct issue; and many of their planning documents (such as their trial plans) contain discussions of relevant ethics issues.

The program includes a disciplinary process to deal with complaints of conduct violative of the Model Rules of Professional Conduct. ${ }^{17}$ This feature has enhanced the realism of the simulations from the perspective of sensitivity to ethics concerns. ${ }^{18}$

The benefits to students from playing the role of a particular client for a long term have been greater than we anticipated. Many students have reported that they have obtained a valuable perspective on the profession that will make them more sensitive to client needs than they might otherwise have been. A few have reported a feeling of helplessness from the client's perspective,

17. Model Rules of PRofessional ConduCt (1992).

18. In the seven years of the program's operation, four reports of misconduct have been filed. One of those has resulted in the imposition of discipline, a public reprimand. When a report is filed, a process analogous to a typical state bar disciplinary process is set in motion. 
particularly when the service being provided them by their lawyers was less than might be expected.

The simulated client service is designed to be comprehensive. Associates are assigned to represent clients from an initial intake interview all the way through to the logical end of the matter. For example, in the trial scenario, students will experience client interviews, fact investigation, research and writing activities, filing pleadings, motion practice, discovery practice, a trial, and finally, an appeal. Students are able to witness the results of their representation at each stage of the problem. Furthermore, because the tasks are related, students must rely upon their prior work and conduct with their client, opposing counsel, and the court. The students' observation of and reliance on the results of each phase of client representation reinforces their learning about the activities.

Besides the obvious benefits of this comprehensive approach to the learning of professional skills, there are also dramatic advantages to the teaching of professional ethics. Unlike teaching professional ethics in isolated activities, such as a negotiation or interviewing exercise that lasts for only a short amount of time, the long-running scenarios of William and Mary's program present students with continuous ethical challenges. A poor relationship begun must be repaired, unethical behavior of fellow members of the bar must be reported under appropriate circumstances, and the consequences of lawyering conduct are realized. The long-term client relationship developed in the program provides students with a greater opportunity to contextualize their conduct and reflect upon the effects of their past actions.

Because the program replaces other courses in the curriculum, it costs relatively little more than would be spent on the replaced courses. The program eliminated from our curriculum the research and writing course (an item on which many schools spend considerable resources), a required professional ethics course, and the following limited enrollment electives: a negotiation course; an interviewing and counseling course; and a basic trial practice course. Devoted to the program's operation are portions of the teaching load of four tenured faculty, twelve adjunct faculty, fourteen teaching assistants, and an administrative assistant. The total cost of the program is approximately equal to the cost of offering the replaced courses. ${ }^{19}$

IV

RELEVANT SURVEY DATA

One of the survey's thirty-one questions (question 30) asked the respondents

19. A fairly detailed analysis of the program's cost was done in 1991 and is available from the author upon request. The estimates of research and writing program costs were based on the results of a 1990 Legal Writing Institute survey of research and writing programs at American law schools. See J. Christopher Rideout \& Jill J. Ramsfield, Legal Writing: A Revised View, 69 WASH L.R. 35, 99 n.2 (1994) (citing the Legal Writing Institute's survey on legal writing programs: Jill J. Ramsfield \& Brien C. Walton, Survey of Legal Research and Writing Programs (1992) (unpublished manuscript on file with the Washington Law Review)). 
to evaluate on a scale of one (low) to five (high) how well their law school experience prepared them to engage in the following alphabetically arranged list of activities:

Appellate Practice
Attracting and Retaining Clients
Client Counseling
Computer-assisted Legal Research
Drafting Legal Instruments
Drafting Office Memoranda
Knowledge of Substantive Law
Legal Analysis
Litigation Techniques
Negotiation Techniques
Oral Communication
Planning Litigation Strategies
Procedural Law
Professional Ethics
Research Techniques
Time Management/Billing
Trial Practice
Written Communication

Regarding the same list of activities, lawyers were asked, in the previous question, whether law schools should emphasize or de-emphasize the teaching of each activity in their curricula. ${ }^{20}$

For the sake of analysis, I have organized the list of topics into the following categories: "Traditional Legal Research and Writing Skills"; "Expanded Skills Program/Clinical Skills"; "Full Law School Experience Skills"; "Professional Ethics"; and "Miscellaneous Practice Skills." Comparing the mean of the scores from graduates of the three schools with traditional skills and ethics curricula with the mean scores from William and Mary legal skills program graduates yields the results in Charts A and B. (All charts appear in the appendix, at pages 279-286.)

To determine the statistical significance of the differences in means reflected on Charts A, C, and D, I used the t-test for unequal groups. This test accounts for the size of the samples, differences in sample sizes, and the possibility of error. A number between zero and one (called the "significance score") is produced that represents the likelihood that a difference in means between the compared groups is the result of error or chance. The closer the significance score is to zero, the more significant and real is the difference between the compared means; the closer the significance score is to one, the less significant and real is the difference between the means. 
In medical science, it is common to use a "less than .01" significance level; in social science, it is common to use either a "less than .05" or "less than .10" significance level. When the significance score produced by the t-test is higher than $.01, .05$, or .10 , depending on the appropriate choice of significance level, the difference in means is deemed not significant. Statistically speaking, such means are not significantly different from each other. Meeting these significance levels, in essence, means that the difference in means is less than 1 percent, 5 percent, or 10 percent, respectively, likely to have been the result of sample error or chance.

Charts $\mathrm{A}, \mathrm{C}$, and D include the significance score that resulted from doing the t-test on the data. Using a .05 significance level, the more demanding of the two commonly used social science significance levels, the charts place in bold the differences that are statistically significant and place in bold italic the rather extraordinary significance scores of .000 that indicate a less than five tenthousandths (.0005) error chance.

For this paper's purposes, the focus is on the "Professional Ethics" scores. These scores are compared among the four schools and also with other scores with which there may be some relationship.

\section{A. Comparing Professional Ethics Preparation Scores}

The mean preparation score assigned by graduates of the three traditional professional ethics curricula schools is 3.61 . The score assigned by students of William and Mary's experiential learning model legal skills program is 4.05 . The difference between the scores is significant, 16.9 percent with a significance score of .000 . Each of the three traditional schools' graduates assigned similar scores: School 1, 3.63; School 2, 3.66; and School 3, 3.53. ${ }^{21}$ Thus, the difference between the responses of the experiential learning model graduates and the traditional curriculum graduates appears not to be the result of an aberrant score from one of the three schools' graduates. This data is consistent with internal evaluative mechanisms that we have employed in the program's sevenyear existence. ${ }^{22}$

21. The University of Washington, another school that is similar in many ways to the four schools in this study, recently reported a score similar to that of the three traditional ethics teaching curricula schools in this survey. The University of Washington survey was an internal alumni survey effort not unlike the William and Mary Curriculum Committee Survey reported in notes 22 and 28, infra. Wallace Loh, The MacCrate Report-Heuristic or Prescriptive?, 69 WASH. L. REV. 505, 509 (1994) (reporting a 3.48 mean score in response to the question "How well did the law school educate you [with respect tol professional ethics?").

22. Beginning with the first class of students through the program, we administered a multiple choice examination covering the law of lawyering. The exam is patterned after the Multistate Professional Responsibility Exam. Included among the questions on that test has always been a set of twelve questions that were included on the free-standing professional responsibility course exam administered to the last group of William and Mary students through the traditional free-standing course in 1989. From that first year and consistently for all seven years, Legal Skills students have as a group scored from $10 \%$ to $14 \%$ higher on those common questions than had the previous, traditionally taught William and Mary Legal Profession students. 
To view these responses from a different statistical perspective that is more oriented to individual responses, one can calculate the percentage of graduates from each of the four schools who assigned the score of one or two on the five point scale (an unfavorable score) in response to the professional ethics preparation question. This could then be compared with the percentage of graduates from each of the four schools who assigned the score four or five on the five point scale (a favorable score) in response to the preparation question. That calculation yields the following results:

\begin{tabular}{|c|c|c|c|}
\hline Percentage & $\frac{\text { Favorable }}{(4 \text { or } 5)}$ & $\frac{\text { Unfavorable }}{(1 \text { or } 2)}$ & $\underline{\text { Fav./Unf }}$ \\
\hline School 1 & 51.1 & 13.3 & $3.83 / 1$ \\
\hline School 2 & 57.1 & 10.2 & $5.60 / 1$ \\
\hline School 3 & 55.5 & 7.3 & $7.63 / 1$ \\
\hline W\&M (91-93) & 72.2 & 5.1 & $14.25 / 1$ \\
\hline
\end{tabular}

One argument would suggest that the guided, designed experience that William and Mary students receive in the legal skills program is less valuable for professional ethics preparation than would be a live client clinic or a clerkship or externship outside the law school. Without doubting the benefits of an inhouse clinic or an externship, which are unquestionably great, Chart $\mathrm{C}$ indicates that the mean preparation scores given by students at Schools 1,2 , and 3 who participated in clinics and externships is not markedly different from nonparticipating students and continues to be significantly lower than the legal skills program graduates of William and Mary.

Additionally, during 1993, the Law School's Ad Hoc Committee to Review the Curriculum surveyed 1983-92 William and Mary graduates, asking a series of questions about the curriculum. Among those questions were two pages designed to determine the alumni opinion about how well the law school had prepared them to do certain things in the practice. They were asked to rate the school's work on a scale of 1-5. Comparing the answers given by pre-skills program graduates with post-skills program graduates reveals the following:

Question: did the law school do as well as we could?

(percentage change between pre-skills and post-skills program graduates)

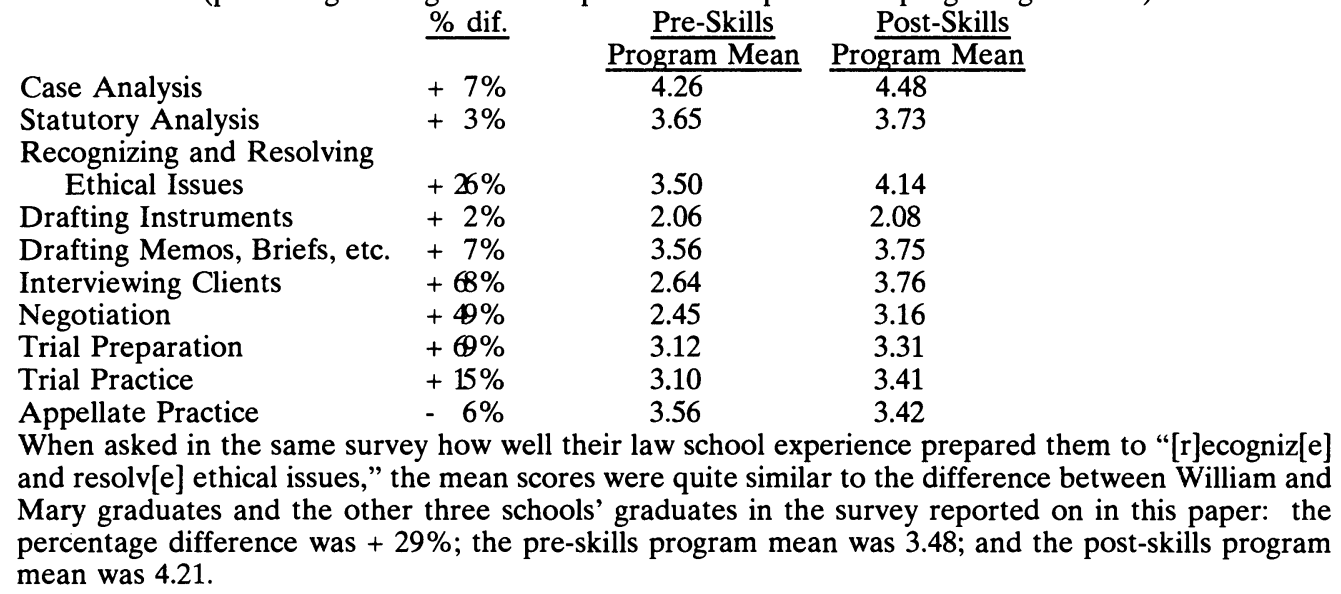




\section{B. Comparing Professional Ethics Preparation Score Differences with Differences in Core Items of Knowledge, Legal Analysis, and Communication Skills}

The next question one might reasonably ask is whether an increase in professional ethics preparation is at a cost to some other, central mission of the law school's curriculum. All law schools hope and expect that their graduates will leave well prepared to perform legal analysis, to be able to communicate well, and to be knowledgeable of substantive law. The last of these three, knowledge of substantive law, has long been thought to be the least important of the three on the sound theory that the essence of legal education is analysis, not rules. ${ }^{23}$ On this proposition, at least, practicing lawyers agree with legal educators. While 90 percent of hiring partners expect new lawyers to bring communication skills to practice, 81 percent expect them to bring analytical skills, and 74 percent expect them to bring sensitivity to professional ethics issues, only 30 percent expect new lawyers to bring knowledge of substantive law with them when they emerge from three years of law school. ${ }^{24}$

Each of the four surveyed schools' graduates assigned high preparation scores in the core topic that represents the entire law school's contribution, legal analysis, ${ }^{25}$ relative to other, important but less central topics such as oral communication, client counseling, drafting legal instruments, litigation techniques, negotiation techniques, planning litigation strategies, and trial practice. The respondents also assigned relatively high preparation scores to written communication. $^{26}$ For each of the four schools, respondents ranked legal analysis and written communication in the top third of areas for which their law schools prepared them. At all but William and Mary, knowledge of substantive law was also included in the top third. At Schools 1, 2, and 3, as well as with William and Mary's 1990 pre-legal skills program graduates, knowledge of substantive law was ranked either first or second in law school preparation among the eighteen topics listed on the survey. William and Mary graduates who had been instructed in the legal skills program ranked knowledge of

¿ $\rightarrow$ Lon L. Fuller, On Teaching Law, 3 STAN. L. REV. 35, 36 (1950) ("There are certain propositions about legal education upon which, I believe, a consensus exists. There is, for example, an almost universal agreement that our primary object is not to impart information. Whatever it is we want the student to get, it is something more durable, more versatile and muscular, than a mere knowledge of rules of law."); Erwin N. Griswold, Law Schools and Human Relations, 1955 WASH. U. L.Q. 217, 229-30 ("It is no longer possible for a student to know all the law. Nor is it necessary or desirable.").

24. Bryant G. Garth \& Joanne Martin, Law Schools and the Construction of Competence, 43 J. LEGAL EDUC. 469, 490 (1993).

25. School 1: 4.09 (ranked 1); School 2: 3.90 (ranked 1); School 3: 4.15 (ranked 2); and William and Mary: 4.04 (ranked 2).

26. School 1: 3.46 (ranked 6); School 2: 3.36 (ranked 6); School 3: 3.88 (ranked 4); William and Mary: 3.92 (ranked 6). 
substantive law seventh. ${ }^{27}$ These graduates also, unlike those of the other schools and their 1990 William and Mary graduate predecessors, assigned scores roughly as high as those assigned to legal analysis and higher than those assigned to knowledge of substantive law to their law school experience in professional ethics analysis skills (16.9 percent higher than the other schools) ${ }^{28}$ and written communication (14.5 percent higher than other schools).

William and Mary's experiential learning model appears to have raised the graduates' perception of preparedness for professional ethics issues to a level approximating that of "Legal Analysis" and exceeding that of "Knowledge of Substantive Law." Most significantly, it appears to have done so without expense and in some respects with a gain to the central goals of legal education. William and Mary lags behind the other three schools only in the category of knowledge of substantive law (4.2 percent lower than the average of Schools 1, 2 , and 3). This phenomenon may be an indication of the accuracy of Anthony Amsterdam's prediction that the allocation of resources to more experiential learning models will reduce the amount of substantive law that a law school can convey through the repetitive doctrinal course model. ${ }^{29}$

Interestingly, the graduates from all four of the surveyed schools concur with what I would expect most academics to say about the relative importance of knowledge of substantive law as a curriculum goal: with only a slight deviation at School 1, they otherwise quite consistently placed "Knowledge of Substantive Law" as the twelfth or lower of eighteen on its list of what they would advise law schools to emphasize. ${ }^{30}$ (See Charts D and E.) Expectedly, perhaps, they ranked its importance for law school emphasis behind "Legal Analysis" (ranked 1 or 2), "Written Communication" (ranked 1 or 2), and "Legal Research Techniques" (ranked 7). Less expectedly, perhaps, they also ranked "Knowledge of Substantive Law" behind, for example, "Professional Ethics" (ranked 10, except at William and Mary), "Client Counseling" (ranked 8), "Drafting Legal Instruments" (ranked 3 or 4), "Oral Communication" (ranked 5 or 6), and "Negotiation Techniques" (ranked 5, except at William and Mary).

A relatively small and statistically insignificant difference (4.2 percent with significance score .325) in "Knowledge of Substantive Law" scores may be the

27. School 1: 4.03 (ranked 2); School 2: 3.80 (ranked 2); School 3: 4.20 (ranked 1); and William and Mary 1990: 4.11 (ranked 1); and William and Mary: 3.88 (ranked 7).

28. When our own Curriculum Committee conducted a survey of alumni in 1994, similar results were obtained. For example, when asked how well prepared they were to deal with ethical and professional responsibility issues, post-skills program respondents indicated a mean score $18 \%$ higher than pre-skills program graduates of our school. See survey results discussed supra note 22.

29. Anthony G. Amsterdam, Clinical Legal Education-A 21st Century Perspective, 34 J. Legal EDUC. 612, 618 (1984).

30. In this regard, this survey's respondents largely agree with earlier ABF-sponsored survey respondents. When asked which areas had been given sufficient attention in law school, knowledge of substantive law was listed by $91 \%$ of respondents (the highest percentage of respondents listing any particular area), and when asked which areas had been given too much attention in law school, knowledge of substantive law was listed by $13 \%$ of respondents (again the highest percentage of respondents listing any particular area). Garth \& Martin, supra note 24, at 479. 
price of an experiential learning model that makes marked improvement (16.9 percent) in professional ethics preparation.

\section{Comparing Professional Ethics Preparation Scores with Central Skills Preparation Scores}

A key hypothesis underlying the experiential learning model is the more students learn about central lawyering activities, the more they will learn about the lawyer's role, and the more they will learn about the attendant professional ethics issues. Stated another way, when the activities of lawyering are taught in conjunction with professional ethics, the more students learn about the activities of lawyering, and the better prepared they will be to deal with the issues of professional ethics. The data reveal a relationship between the preparation scores assigned to various central lawyering activities and those assigned to professional ethics.

William and Mary graduates gave significantly higher scores than did the other graduates to a variety of practice skills areas that are covered in conjunction with professional ethics teaching in the legal skills program. (See Chart A.) For example:

\begin{tabular}{|c|c|c|}
\hline Practice Skills Areas & $\%$ Higher & Significance Score \\
\hline Written Communication & 14.5 & .002 \\
\hline Client Counseling & 87.9 & .000 \\
\hline Drafting Legal Instruments & 42.7 & .000 \\
\hline Litigation Technique & 52.0 & .000 \\
\hline Negotiation Technique & 83.0 & .000 \\
\hline Planning Litigation Strategies & 65.6 & .000 \\
\hline Trial Practice & 41.6 & .000 \\
\hline
\end{tabular}

These skills represent central activities of lawyers in both the litigation and the office practice contexts. In William and Mary's legal skills program, each of these practice skills areas is taught in conjunction with the attendant professional ethics issues, rules, and controversies. For example, client interviewing and counseling is taught in conjunction with the issues involving the lawyer-client relationship, confidentiality, conflicts of interest, and fees. Negotiation techniques and document drafting are taught in conjunction with the obligation of truth-telling to third-parties and role differentiation between lawyers' litigation and planning roles. Litigation and trial skills are taught in conjunction with advocacy roles and various litigation-oriented constraints on lawyer conduct. Research and writing skills are taught in conjunction with diligence and competence issues. ${ }^{31}$ That students make a connection between the activities of the legal profession and the professional responsibilities of lawyers in such a setting is not surprising. This connection may explain why

31. By subject matter design, some of the writing projects also introduce professional responsibility topics such as entry to the bar and reporting misconduct. 
William and Mary graduates give higher scores to preparation for professional ethics issues.

\section{Comparing "Emphasis" Scores with "Preparation" Scores}

Two further questions might reasonably be asked: Do law schools' efforts match lawyers' expressed needs, and are recommended emphasis score differences more or less variant than preparation score differences between those who have been exposed to an experiential learning approach and those who have not?

The survey asked the lawyers whether the skills referred to in Chart A should be emphasized or de-emphasized in law school curricula. (See Chart D.) It was hoped that the lawyers answering this question would take into account the usefulness of the particular skill in their practice and the likelihood that it can be usefully taught in the law school environment.

As indicated by Charts D, E, F, and G, in most categories the differences between the William and Mary graduates' emphasis scores and those of the other three schools are much less significant than the differences in the preparation scores. The narrowness and general insignificance of the differences in emphasis recommendation scores indicates that the graduates of all four schools are now operating in the same legal universe: The same kinds of things are important to their practices; their recommendations to law schools are similar in most respects.

As indicated by the emphasis rankings by school in Chart E, dividing the lawyers by school does little to differentiate them. Lawyers from all four schools uniformly recommend that law schools de-emphasize appellate practice, attracting and retaining clients, and time management/billing (ranked 18, 17, and 16 at each of the four schools). With substantial similarity, each schools' graduates recommend that law schools emphasize legal analysis, written communication, drafting legal instruments, and oral communication. It appears likely that the lawyers from the four schools are living largely in similar circumstances in their post-law school lives.

One noteworthy disparity in the student emphasis rankings of Chart $\mathrm{E}$ is that William and Mary graduates rank professional ethics as their third recommended emphasis item while graduates of the other three schools rank it tenth and eleventh. This outcome parallels the most significant score difference between the three schools and William and Mary reflected in Chart D, which also occurred in the ranking of professional ethics. Several plausible explanations exist for this disparity, but the survey's data does not point conclusively toward any one of the explanations. It may be that because William and Mary graduates perceive themselves to have been better prepared in the professional ethics area, ${ }^{32}$ they either believe that they see or they do see more ethics issues in their practices. An equally plausible explanation is that because the ethics

32. See infra Chart A. 
teaching program was given greater emphasis by their law school, the William and Mary graduates rank it higher on their recommendations for law school emphasis. ${ }^{33}$

Not only are the emphasis score differences far less in magnitude than the preparation differences, they also fluctuate among the different schools more. The William and Mary graduates' preparation score was higher than the combined mean for the other schools in sixteen of eighteen categories and was highest of the four schools in fourteen of eighteen categories; by contrast, it was higher than the combined mean in only six of the eighteen categories and was highest of the four schools in only five of the eighteen categories. In other words, although William and Mary graduates believe that they were better prepared in nearly all categories, they did not uncritically recommend that law schools emphasize everything.

Matching a school's preparation scores with its emphasis scores also yields interesting results. Such a match gives an indication of what lawyers believe is being done well enough, what should be done better, and what should be done to a lesser degree than it is currently being done. The data in Chart $\mathrm{H}$, for example, indicate that schools with traditional skills and professional ethics curricula may be doing better than is needed in teaching the knowledge of substantive law while they may be doing far less well than is needed in crucial skills areas such as client counseling, drafting legal instruments, and negotiation techniques. All of the surveyed schools are reaching closer to the mark on the skill deemed most in need of emphasis according to the surveyed lawyers, written communication, although all four could stand to give this skill greater emphasis. All four are also close to the marks set by their own graduates for preparation in professional ethics, but the William and Mary graduates who were instructed in the experiential learning model have set a considerably higher mark for schools to reach: one that is close to being reached only in the experiential learning model professional ethics program at William and Mary.

Nonetheless, these comparisons between emphasis scores and preparation scores may be misleading in a way not easily evaluated or leveled. Because respondents gave low emphasis ratings to some skill categories that law schools do little or nothing to teach (for example, attracting and retaining clients), it cannot accurately be said that respondents believe that law schools should deemphasize such skills. Respondents may be accounting in their emphasis responses for what they believe law schools can effectively teach as well as what they would find useful to have been taught. These scores may then, be recommendations for emphasis to law schools that are not relative to the degree

33. In an important American Bar Foundation study, Chicago lawyers who were recent graduates of a 1986-91 vintage, surveyed in 1991, ranked "sensitivity to professional ethical concerns" eleventh in importance to their practice on a list of 17 skills and knowledge areas. Garth \& Martin, supra note 24 , at 473 . The authors also conclude, however, that professional responsibility teaching is one of the few areas that is being addressed more effectively in law schools now than it was twenty years ago. Id. at 503 . 
to which law schools currently emphasize the particular topic. This phenomenon may be seen more clearly in Chart I, which compares the preparation and emphasis score ranking within each schools' graduates' responses.

Based on Chart I's comparisons, for example, our own program might do well to diminish attention currently given to appellate practice, computerassisted legal research, and writing in the office memorandum form, while increasing the amount of attention given to general writing, negotiation, and drafting legal instruments. Interestingly, when the program was designed, appellate practice was intentionally de-emphasized from previous curricular forms, and the emphasis was placed on manual rather than computer-assisted legal research. Some, but clearly not all, of the results from those design efforts have been realized.

\section{$\mathrm{V}$}

\section{CONCLUSION}

The survey data indicate that William and Mary's experiential learning model may better prepare lawyers for their inevitable encounters with professional ethics issues. It provides more classroom hours for instruction in the law and ethics of lawyering than does a two- or three-credit, one-semester course. At the same time, it provides an experiential education with respect to the role of lawyers.

Positive reaction to the effects of the legal skills program by graduates, as evidenced by this study, and a consistent stream of positive anecdotal evidence from both judicial and practicing employers, ought to lead schools to experiment with this model. While most of the resource limitation arguments against using an experiential model of teaching are illusory, the internal political disputes among faculty that have hindered some schools' efforts to move in this direction remain a serious impediment to change. Over time, the educational value of the experiential approach and the self-interest of law schools seeking to attract quality students and raise funds from satisfied alumni hopefully will overcome the internal political impediments. 


\section{APPENDIX: \\ CHARTS A-I}

CHART A

Question 30 Mean Scores: "How well did your law school experience prepare you for ?"

Traditional Legal Research and Writing

Course Skills

Appellate Practice

Computer-Assisted Legal Research

Drafting Office Memorandum

Oral Communication

Research Techniques

Written Communication

Expanded Skills Program/Clinical Skills

Client Counseling

Drafting Legal Instruments

Litigation Techniques

Negotiation Techniques

Planning Litigation Strategies

Trial Practice

Full Law School Experience Skills

Knowledge of Substantive Law

Legal Analysis

Procedural Law

Professional Ethics

Miscellaneous Practice Skills

Attracting and Retaining Clients

Time Management/Billing

$\begin{array}{llll}3.11 & 3.25 & +6.6 & .347 \\ 3.62 & 4.07 & +17.2 & \mathbf{. 0 0 0} \\ 3.06 & 3.96 & +43.7 & \mathbf{. 0 0 0} \\ 3.03 & 3.20 & +8.4 & .181 \\ 3.81 & 3.97 & +5.7 & .161 \\ 3.55 & 3.92 & +14.5 & \mathbf{. 0 0 2} \\ & & & \\ 2.24 & 3.33 & +87.9 & \mathbf{. 0 0 0} \\ 2.43 & 3.04 & +42.7 & \mathbf{. 0 0 0} \\ 2.48 & 3.25 & +52.0 & \mathbf{. 0 0 0} \\ 2.12 & 3.05 & +83.0 & \mathbf{. 0 0 0} \\ 1.90 & 2.49 & +65.6 & \mathbf{. 0 0 0} \\ 2.49 & 3.11 & +41.6 & \mathbf{. 0 0 0} \\ & & & \\ 4.00 & 3.88 & -4.2 & .325 \\ 4.04 & 4.04 & \text { even } & .985 \\ 3.24 & 3.32 & +3.6 & .516 \\ 3.61 & 4.05 & +16.9 & \mathbf{. 0 0 0} \\ & & & \\ 1.53 & 1.89 & +67.9 & \mathbf{. 0 0 9} \\ 1.53 & 1.93 & +75.5 & \mathbf{. 0 0 1}\end{array}$

* These percentage of difference ("\% diff.") figures were calculated as follows: The scale for the mean scores to be compared was 1-5. Because the range is 4 and not 5 , and because the scale begins at one and not zero, the difference in mean scores on the 1-5 scale of, for example, 3.55 and 3.92 is really the difference between 2.55 and 2.92 . Thus, the calculation proceeds by comparing the difference (.37) to the lower of the two compared numbers (2.55), producing a difference of $14.5 \%$. 


\section{CHART B}

Question 30 Mean Scores: "How well did your law school experience prepare you for ?"

\begin{tabular}{|c|c|c|c|c|c|}
\hline & $\mathbf{n}=98$ & $\mathrm{n}=110$ & $\mathrm{n}=90$ & $\begin{array}{c}\mathrm{W} \& \mathrm{M}^{*} \\
90 \\
\mathrm{n}=20\end{array}$ & $\begin{array}{l}\text { W\&M } \\
91-93 \\
n=79\end{array}$ \\
\hline \multicolumn{6}{|l|}{ Traditional Legal Research and Writing } \\
\hline \multicolumn{6}{|l|}{ Course Skills } \\
\hline Appellate Practice & 2.95 & 3.02 & 3.38 & 2.59 & 3.25 \\
\hline Computer-Assisted Legal Research & 3.60 & 3.38 & 3.92 & 3.72 & 4.07 \\
\hline Drafting Office Memorandum & 2.87 & 3.08 & 3.23 & 2.94 & 3.96 \\
\hline Oral Communication & 3.07 & 2.79 & 3.26 & 3.39 & 3.20 \\
\hline Research Techniques & 3.88 & 3.75 & 3.81 & 3.39 & 3.97 \\
\hline Written Communication & 3.46 & 3.37 & 3.88 & 3.67 & 3.92 \\
\hline \multicolumn{6}{|l|}{ Expanded Skills Program/Clinical Skills } \\
\hline Client Counseling & 2.11 & 1.94 & 2.73 & 2.17 & 3.33 \\
\hline Drafting Legal Instruments & 2.32 & 2.36 & 2.65 & 2.67 & 3.04 \\
\hline Litigation Techniques & 2.45 & 2.53 & 2.44 & 2.83 & 3.25 \\
\hline Negotiation Techniques & 2.23 & 1.99 & 2.15 & 2.56 & 3.05 \\
\hline Planning Litigation Strategies & 1.91 & 1.89 & 1.91 & 1.94 & 2.49 \\
\hline Trial Practice & 2.46 & 2.62 & 2.37 & 2.78 & 3.11 \\
\hline \multicolumn{6}{|l|}{ Full Law School Experience Skills } \\
\hline Knowledge of Substantive Law & 4.03 & 3.80 & 4.20 & 4.11 & 3.88 \\
\hline Legal Analysis & 4.09 & 3.90 & 4.15 & 4.06 & 4.04 \\
\hline Procedural Law & 3.26 & 3.32 & 3.10 & 3.56 & 3.32 \\
\hline Professional Ethics & 3.63 & 3.66 & 3.53 & 3.94 & 4.05 \\
\hline \multicolumn{6}{|l|}{ Miscellaneous Practice Skills } \\
\hline Attracting and Retaining Clients & 1.55 & 1.48 & 1.58 & 1.78 & 1.89 \\
\hline Time Management/Billing & 1.44 & 1.56 & 1.60 & 1.67 & 1.93 \\
\hline
\end{tabular}

* Differences between the 1990 (pre-legal skills program) and 1991-93 William and Mary graduates did not meet significance tests, largely because of the small size of the 1990 sample.

CHART C

Professional Ethics Preparation Mean Scores by School, Clinic Participation, and Clerkship/Externship

$\begin{array}{lccccccc} & \text { Sch.1 } & \begin{array}{c}\text { Sch.2 } \\ \mathrm{n}=98\end{array} & \begin{array}{c}\text { Sch.3 } \\ \mathrm{n}=110\end{array} & \begin{array}{c}\text { Avg. } \\ \text { of 3 }\end{array} & \begin{array}{c}\text { with } \\ \text { clinic }\end{array} & \begin{array}{c}\text { with } \\ \text { clerkship/ } \\ \text { externship } \\ \mathrm{n}=112\end{array} & \begin{array}{c}\text { W\&M } \\ 91-93 \\ \mathrm{n}=79\end{array} \\ \begin{array}{l}\text { Professional Ethics } \\ \begin{array}{c}\text { Preparation Mean } \\ \text { Significance Score }\end{array}\end{array} & 3.63 & 3.66 & 3.53 & 3.61 & \begin{array}{c}3.72 \\ \mathbf{. 0 0 3}\end{array} & \begin{array}{c}3.68 \\ \mathbf{. 0 0 1}\end{array} & 4.05\end{array}$




\section{CHART D}

Question 29 Mean Scores: Suggested Emphases for Law Schools

Traditional Legal Research and Writing

\author{
trad. skills/ \\ ethics schools \\ $\mathrm{n}=298$
}

Course Skills

Appellate Practice

Computer-Assisted Legal Research

Drafting Office Memorandum

Oral Communication

Research Techniques

Written Communication

Expanded Skills Program/Clinical Skills

Client Counseling

Drafting Legal Instruments

Litigation Techniques

Negotiation Techniques

Planning Litigation Strat.

Trial Practice

Full Law School Experience Skills

Knowledge of Substantive Law

Legal Analysis

Procedural Law

Professional Ethics

Miscellaneous Practice Skills

Attracting and Retaining Clients

Time Management/Billing
(1-5)

W\&M

91-93

$\mathrm{n}=79$

(1-5)

$\%$ diff.

sign.

score

$(0-1)$

$\begin{array}{llcl}2.88 & 2.68 & -11.9 & .132 \\ 3.81 & 3.97 & +5.7 & .195 \\ 3.58 & 3.75 & +7.4 & .223 \\ 4.28 & 4.14 & -4.5 & .210 \\ 4.03 & 4.14 & +3.6 & .289 \\ 4.32 & 4.33 & 0 & .963 \\ & & & \\ 4.01 & 4.03 & +1.0 & .865 \\ 4.37 & 4.20 & -5.3 & .122 \\ 4.07 & 3.84 & -6.0 & .037 \\ 4.22 & 3.97 & -8.4 & .029 \\ 3.67 & 3.53 & -5.5 & .269 \\ 3.76 & 3.63 & -4.9 & .298 \\ & & & \\ 3.84 & 3.71 & -4.8 & .308 \\ 4.31 & 4.48 & +5.1 & .059 \\ 3.96 & 4.05 & +3.0 & .465 \\ 3.90 & 4.23 & +11.4 & . \mathbf{0 0 4} \\ & & & \\ 3.43 & 3.23 & -8.9 & .142 \\ 3.29 & 3.10 & -9.0 & .203\end{array}$




\section{CHART E}

Question 29 Summary: Rank within Each of the Four Schools

$\begin{array}{lllll}\text { Sch. } 1 & \text { Sch. } 2 & \text { Sch.3 Avg. of } 3 \quad \text { W\&M }\end{array}$

Traditional Legal Research and

Writing Course Skills

Appellate Practice

Computer-Assisted Legal Research

Drafting Office Memorandum

Oral Communication

Research Techniques

Written Communication

Expanded Skills Program/Clinical

Skills

Client Counseling

Drafting Legal Instruments

Litigation Techniques

Negotiation Techniques

Planning Litigation Strategies

Trial Practice

Full Law School Experience Skills

Knowledge of Substantive Law

Legal Analysis

Procedural Law

Professional Ethics

Miscellaneous Practice Skills

Attracting and Retaining Clients

Time Management/Billing

$\begin{array}{rrrrr}18 & 18 & 18 & 18 & 18 \\ 12 & 8 / 9 & 15 & 12 & 9 \\ 15 & 15 & 12 & 15 & 12 \\ 2 & 5 & 3 & 4 & 5 / 6 \\ 9 & 6 & 8 & 7 & 5 / 6 \\ 5 & 1 & 1 & 1 & 2 \\ & & & & \\ 6 / 7 & 10 & 7 & 8 & 8 \\ 1 & 3 & 2 & 3 & 4 \\ 6 / 7 & 7 & 6 & 6 & 11 \\ 4 & 4 & 5 & 5 & 10 \\ 14 & 13 & 13 & 14 & 15 \\ 13 & 14 & 11 & 13 & 14 \\ & & & & \\ 8 & 12 & 14 & 11 & 13 \\ 3 & 2 & 4 & 2 & 1 \\ 11 & 8 / 9 & 9 & 9 & 7 \\ 10 & 11 & 10 & 10 & 3 \\ & & & & \\ 16 & 16 & 16 & 16 & 16 \\ 17 & 17 & 17 & 17 & 17\end{array}$




\section{CHART F \\ Questions 29 and 30: Comparison of "Emphasis" and "Preparation" Score Differences (range of means)}

difference between highest and lowest mean of individual schools

Q29

Q30

Traditional Legal Research and Writing Course Skills Appellate Practice

Computer-Assisted Legal Research

Drafting Office Memorandum

Oral Communication

Research Techniques

.48

Written Communication

Expanded Skills Program/Clinical Skills

Client Counseling

Drafting Legal Instruments

Litigation Techniques

Negotiation Techniques

Planning Litigation Strategies

Trial Practice

Full Law School Experience Skills

Knowledge of Substantive Law

Legal Analysis

Procedural Law

Professional Ethics

Miscellaneous Practice Skills

Attracting and Retaining Clients

Time Management/Billing 


\section{CHART G \\ Questions 29 and 30: Comparison of "Emphasis" and "Preparation" \\ Score Differences}

absolute value of difference between

W\&M mean and the combined mean of

Schools 1, 2, and 3
Q 29
Q 30

Traditional Legal Research and Writing Course Skills

Appellate Practice

Computer-Assisted Legal Research

.14

Drafting Office Memorandum

Oral Communication

Research Techniques

Written Communication

Expanded Skills Program/Clinical Skills

Client Counseling

Drafting Legal Instruments

Litigation Techniques

Negotiation Techniques

Planning Litigation Strategies

Trial Practice

Full Law School Experience Skills

Knowledge of Substantive Law

Legal Analysis

Procedural Law

Professional Ethics

Miscellaneous Practice Skills

Attracting and Retaining Clients

Time Management/Billing
$.17 \quad .45$

$.17 \quad .90$

$\begin{array}{ll}.14 & .17\end{array}$

$.11 \quad .16$

$\begin{array}{ll}.01 & .37\end{array}$

$\begin{array}{ll}.02 & 1.09\end{array}$

$\begin{array}{ll}.17 & .61\end{array}$

$\begin{array}{ll}.23 & .57\end{array}$

$\begin{array}{ll}.25 & .97\end{array}$

$.14 \quad .59$

$\begin{array}{ll}.13 & .62\end{array}$

$.13 \quad .12$

$\begin{array}{ll}.17 & 0\end{array}$

$\begin{array}{ll}.09 & .08\end{array}$

$\begin{array}{ll}.33 & .44\end{array}$

$.20 \quad .36$

$.19 \quad .36$ 


\section{CHART H}

Questions 29 and 30: Comparison by School of "Emphasis" and "Preparation" Scores

\begin{tabular}{|c|c|c|c|c|}
\hline & \multicolumn{4}{|c|}{$\begin{array}{l}\text { emphasis score/preparation score } \\
\text { "need it"/"got it" }\end{array}$} \\
\hline & Sch.1 & Sch. 2 & Sch.3 & $\begin{array}{l}\text { W\&M } \\
91-93\end{array}$ \\
\hline \multicolumn{5}{|l|}{ Traditional Legal Research and Writing } \\
\hline \multicolumn{5}{|l|}{ Course Skills } \\
\hline Appellate Practice & $2.75 / 2.95$ & $2.92 / 3.02$ & $2.99 / 3.38$ & $2.68 / 3.25$ \\
\hline Computer-Assisted Legal Research & $3.80 / 3.60$ & $3.93 / 3.38$ & $3.67 / 3.92$ & $3.97 / 4.07$ \\
\hline Drafting Office Memorandum & $3.56 / 2.87$ & $3.37 / 3.08$ & $3.85 / 3.23$ & $3.75 / 3.96$ \\
\hline Oral Communication & $4.29 / 3.07$ & $4.16 / 2.79$ & $4.40 / 3.26$ & $4.14 / 3.20$ \\
\hline Research Techniques & $3.97 / 3.88$ & $4.05 / 3.75$ & $4.07 / 3.81$ & $4.14 / 3.97$ \\
\hline Written Communication & $4.19 / 3.46$ & $4.34 / 3.37$ & $4.45 / 3.88$ & $4.33 / 3.92$ \\
\hline \multicolumn{5}{|l|}{ Expanded Skills Program/Clinical Skills } \\
\hline Client Counseling & $4.08 / 2.11$ & $3.88 / 1.94$ & $4.08 / 2.73$ & $4.03 / 3.33$ \\
\hline Drafting Legal Instruments & $4.39 / 2.32$ & $4.28 / 2.36$ & $4.44 / 2.65$ & $4.20 / 3.04$ \\
\hline Litigation Techniques & $4.08 / 2.45$ & $3.97 / 2.53$ & $4.16 / 2.44$ & $3.84 / 3.25$ \\
\hline Negotiation Techniques & $4.22 / 2.23$ & $4.22 / 1.99$ & $4.22 / 2.15$ & $3.97 / 3.05$ \\
\hline Planning Litigation Strategies & $3.63 / 1.91$ & $3.63 / 1.89$ & $3.78 / 1.99$ & $3.53 / 2.49$ \\
\hline Trial Practice & $3.79 / 2.46$ & $3.60 / 2.37$ & $3.93 / 2.78$ & $3.63 / 3.11$ \\
\hline \multicolumn{5}{|l|}{ Full Law School Experience Skills } \\
\hline Knowledge of Substantive Law & $3.98 / 4.03$ & $3.78 / 3.80$ & $3.75 / 4.20$ & $3.71 / 3.88$ \\
\hline Legal Analysis & $4.27 / 4.09$ & $4.30 / 3.90$ & $4.36 / 4.15$ & $4.48 / 4.04$ \\
\hline Procedural Law & $3.94 / 3.26$ & $3.93 / 3.32$ & $4.02 / 3.10$ & $4.05 / 3.32$ \\
\hline Professional Ethics & $3.95 / 3.63$ & $3.81 / 3.66$ & $3.97 / 3.53$ & $4.23 / 4.05$ \\
\hline \multicolumn{5}{|l|}{ Miscellaneous Practice Skills } \\
\hline Attracting and Retaining Clients & $3.49 / 1.55$ & $3.29 / 1.48$ & $3.55 / 1.58$ & $3.23 / 1.89$ \\
\hline Time Management/Billing & $3.32 / 1.44$ & $3.14 / 1.56$ & $3.43 / 1.60$ & $3.10 / 1.93$ \\
\hline
\end{tabular}




\section{CHART I}

Questions 29 and 30: Comparison by School of "Emphasis" and "Preparation" Scores Rank

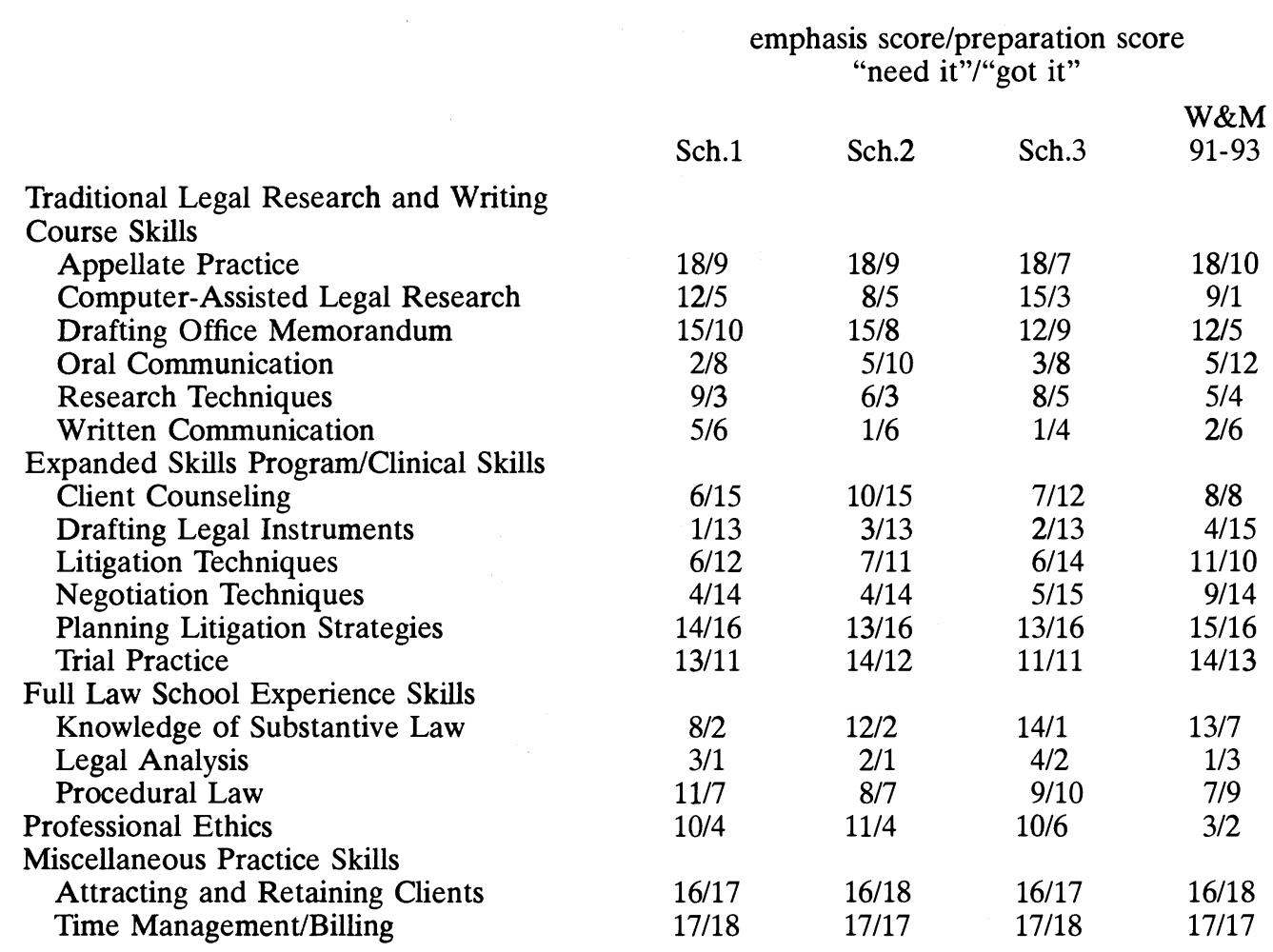

